\title{
Endogenous Ciliary Neurotrophic Factor Is a Lesion Factor for Axotomized Motoneurons in Adult Mice
}

\author{
Michael Sendtner, ${ }^{1}$ Rudolf Götz, ${ }^{1}$ Bettina Holtmann, ${ }^{1,2}$ and Hans Thoenen ${ }^{2}$ \\ ${ }^{1}$ Clinical Research Unit for Neuroregeneration, Department of Neurology, University of Würzburg, D-97080 Würzburg, \\ Germany, and 2Department of Neurochemistry, Max-Planck-Institut for Psychiatry, D-82152 Martinsried, Germany
}

\begin{abstract}
Ciliary neurotrophic factor (CNTF) is an abundant cytosolic molecule in myelinating Schwann cells of adult rodents. In newborn animals in which CNTF is not yet expressed, exogenous CNTF that is locally administered very effectively protects motoneurons from degeneration by axotomy. To evaluate whether endogenous CNTF, released after nerve injury from the cytosol of Schwann cells, supports motoneuron survival, we transected the facial nerve in 4-week-old pmn mice. In this mouse mutant a rapidly progressing degenerative disease of motoneurons starts by the third postnatal week at the hindlimbs and progresses to the anterior parts of the body, leading to death by the seventh to eighth week. Apoptotic death of motoneurons can be observed during this period, as revealed by TUNEL staining. In 6 -week-old unlesioned pmn mice $\sim 40 \%$ of facial motoneurons have degenerated. Facial nerve lesion dra-
\end{abstract}

matically increased the number of surviving motoneurons in $p m n$ mice. This protective effect was absent in pmn mice lacking endogenous CNTF. Quantitative analysis of leukemia inhibitory factor (LIF) mRNA expression revealed that the dramatic upregulation seen in wild-type mice after peripheral nerve lesion did not occur in pmn mice. Therefore, endogenous LIF cannot compensate for the lack of CNTF in pmn crossbred with CNTF knock-out mice. Thus, endogenous CNTF released from lesioned Schwann cells supports the survival of axotomized motoneurons under conditions in which motoneurons are in the process of rapid degeneration.

Key words: ciliary neurotrophic factor; leukemia inhibitory factor; CNTF; LIF; motoneurons; facial nucleus; nerve lesion; axotomy; cell death; apoptosis
Ciliary neurotrophic factor (CNTF) was discovered as a component of embryonic chick eye that supported the survival of isolated ciliary neurons in culture (Adler et al., 1979; Barbin et al., 1984). On the basis of these studies it was assumed that this factor is produced and secreted from target cells innervated by ciliary neurons. Further investigations demonstrated that CNTF has a much broader spectrum of actions, including sensory, sympathetic, and motoneurons. The identification of very high levels of CNTF-like biological activity in the sciatic nerve of adult animals was thought to represent CNTF transported retrogradely from target tissues of responsive neurons (Manthorpe and Varon, 1985; Manthorpe et al., 1986). The subsequent molecular cloning of CNTF (Lin et al., 1989; Stöckli et al., 1989) revealed that the CNTF protein lacks a hydrophobic leader sequence and is not secreted from transfected cells (Lin et al., 1989; Stöckli et al., 1989). Intense CNTF immunoreactivity was identified in the cytosol of Schwann cells of adult rat peripheral nerves (Stöckli et al., 1991; Rende et al., 1992). Moreover, CNTF mRNA expression in skeletal muscle was below the detection limit (Stöckli et al., 1989), and CNTF mRNA expression in peripheral nerves proved to be extremely low during the physiological cell death

Received April 16, 1997; revised June 19, 1997; accepted July 1, 1997.

This work was initiated at the Max-Planck-Institut for Psychiatry in Martinsried and completed at the Department of Neurology, University of Würzburg. This study was supported by the Deutsche Forschungsgemeinschaft, Grant To 61/8, and the Bundesministerium für Bildung und Forschung, Grant 01 KO 9403. We thank Georg Kreutzberg for many helpful comments and discussions; Patrick Carroll for helping with the genotyping of the CNTF $-/-$ mice; and Waltraud Komp, Heike Döppler, and Anita Kraiss for technical assistance.

Correspondence should be addressed to Dr. Michael Sendtner, Clinical Research Unit for Neuroregeneration, Department of Neurology, University of Würzburg, Josef-Schneider-Strasse 11, D-97080 Würzburg, Germany.

Copyright (C) 1997 Society for Neuroscience $0270-6474 / 97 / 176999-08 \$ 05.00 / 0$ period of CNTF responsive neurons (Stöckli et al., 1991). CNTF expression in peripheral nerves is increasing continuously between the end of the first and fourth postnatal week. The developmental time course of CNTF production in Schwann cells, together with the observation that CNTF has a very effective protective action on axotomized motoneurons in newborn animals, has led to the hypothesis that the abundant CNTF protein in adult myelinating Schwann cells could act as a lesion factor after nerve injury (Sendtner et al., 1992c, 1994). However, studies in which peripheral nerves were lesioned in CNTF knock-out mice (Masu et al., 1993; Sendtner et al., 1996) were inconclusive, because most of the motoneurons survived in these mice after a lesion at an age of 4 weeks. This probably is attributable to the fact that in the later postnatal phase axotomy-initiated degeneration of motoneurons occurs much more slowly. Thus the lesionmediated enhanced synthesis of other neurotrophic factors such as leukemia inhibitory factor (LIF), brain-derived neurotrophic factor (BDNF), glial-derived neurotrophic factor (GDNF), and insulin-like growth factor-I (IGF-I) comes into play, which occurs with some delay after lesion and thus no longer permits the rescue of motoneurons in newborn animals in which motoneuron degeneration occurs more rapidly (Meyer et al., 1992; Sendtner et al., 1992a; Yan et al., 1992; Hughes et al., 1993; Ishii et al., 1993; Koliatsos et al., 1993; Cheema et al., 1994; Henderson et al., 1994; Zurn et al., 1994; Li et al., 1995; Oppenheim et al., 1995; Trupp et al., 1995).

To analyze the function of $\mathrm{CNTF}$ as a lesion factor, we transected facial nerves in 4-week-old pmn mice (Schmalbruch et al., 1991; Sendtner et al., 1992b). In this mouse mutant motoneurons degenerate rapidly at this age, and a lesion factor becoming available immediately could be assumed to have a protective 
effect. Indeed, facial nerve lesion in 4-week-old pmn mutant mice prevented motoneuron cell death. The rescue effect was reduced dramatically in pmn mice lacking CNTF, indicating that the endogenous CNTF rescues motoneurons from cell death after nerve lesion.

\section{MATERIALS AND METHODS}

pmn and CNTF knock-out mice. Homozygous CNTF-deficient female mice on a 129/SV $\times$ C57BL/6 genetic background (Masu et al., 1993) were crossbred with pmn heterozygous mice (NMRI genetic background). F1 animals were crossbred, and F2 offspring were tested for homozygous pmn mice. Only animals from F2 and successive generations were used in this study. The CNTF gene mutation was detected by Southern blot analysis from tail biopsies, as described (Masu et al., 1993). Mice heterozygous for the pmn mutation could be detected only by their offspring, and these mice were used for expanding the mouse colony used in this study. pmn mice on this mixed genetic background showed a similar phenotype to those on the NMRI genetic background. The first signs of disease were observed by muscle weakness of hindlimbs between postnatal day 16 and 20 , and the mice died after the fourth postnatal week by respiratory failure. Homozygous pmn mice lacking CNTF did not differ from $p m n / \mathrm{CNTF}+/+$ mice with respect to development of first disease symptoms, course of the disease, postnatal survival, or other obvious parameters.

Facial nerve transection. pmn and control littermates were weaned at an age of 3 weeks, and facial nerve transection was performed unilaterally at an age of $28 \mathrm{~d}$. They were anesthetized deeply with ether, and the facial nerve was exposed on the right side after the skin behind the ear was sectioned. At a position $\sim 1 \mathrm{~mm}$ distal to the foramen stylomastoideum, the nerve was transected with fine scissors. The distal nerve stump was deflected, and the skin wound was closed with silk (Ethicon 6-0). The effect of facial nerve transection was detectable by unilateral absence of whisker movement. At 42 d, the mice were killed by an overdose of anesthetics and fixed by transcardial perfusion with $4 \%$ paraformaldehyde in $0.1 \mathrm{M}$ phosphate buffer, pH 7.2.

Histological analysis. Brain and brainstem were prepared from perfused mice and post-fixed for at least 3 additional hours in the same fixative. The brainstem was embedded in paraffin, and serial sections ( 7 $\mu \mathrm{m})$ were prepared and Nissl-stained, as described (Sendtner et al., 1990; Masu et al., 1993). The number of facial motoneurons exhibiting Nissl structure and a clearly detectable nucleolus was counted in every fifth section. Correction for split nucleoli was applied, as described previously (Masu et al., 1993). Briefly, the diameters of nucleoli were determined in facial motoneurons both on the lesioned and unlesioned sides in each animal, and the raw neuronal counts were corrected according to the formula by Abercrombie.

Terminal deoxynucleotidyl transferase-mediated dUTP-X nick end labeling (TUNEL) staining. For quantitative determination of apoptotic cells in the facial nucleus of pmn mice, paraffin serial sections $(7 \mu \mathrm{m})$ were prepared from brainstems of 28 -d-old $p m n / \mathrm{CNTF}+1+(n=4)$ and $p m n /$ CNTF $-/-$ mice $(n=2)$. The right facial nerve in these mice had been transected at postnatal day 21 . After Nissl staining the facial nuclei were identified on both sides, and all sections spanning this anatomical region were used for further analysis. Sections were destained and rehydrated by washing in xylene and subsequent incubation in 100, 95, 90 , 80 , and $70 \%$ ethanol. Then slides were rinsed with PBS for $30 \mathrm{~min}$ and incubated with permeabilization solution $(0.1 \%$ Triton $\mathrm{X}-100$ in $0.1 \%$ sodium citrate) for $2 \mathrm{~min}$ on ice $\left(4^{\circ} \mathrm{C}\right)$. After rinsing the slides twice with PBS, we added the TUNEL reaction mixture [containing terminal deoxynucleotidyl transferase (TdT) and fluorescin-dUTP] for $60 \mathrm{~min}$ at $37^{\circ} \mathrm{C}$, according to the manufacturer's instructions (In Situ Cell Death Kit, AP, Boehringer Mannheim, Mannheim, Germany). Slides were rinsed three times with PBS and incubated with anti-fluorescin antibody conjugated with alkaline phosphatase for $30 \mathrm{~min}$ at $37^{\circ} \mathrm{C}$. To avoid evaporation and consequent destruction of the sections, we performed both incubation steps in a humidified chamber, and we protected the sections with a coverslip. Sections then were rinsed three times with PBS before the chromogen/substrate solution (New Fuchsin Substrate System, Dako, Hamburg, Germany) was added for $10 \mathrm{~min}$ at room temperature. Levamisole was added at a concentration of $1 \mathrm{~mm}$ for blocking endogenous AP activity.

Slides finally were mounted with coverslips and analyzed under the light microscope. The number of apoptotic residues was counted in each section of the facial nuclei both on the unlesioned and lesioned sides.
Determination of LIF $m R N A$. Total RNA was isolated from the sciatic nerves of 3-week-old pmn and control mice. A LIF-specific primer (5'-ACGGTACTTGTTGCACAGAC) was annealed at $70^{\circ} \mathrm{C}$ to $100 \mathrm{ng}$ of RNA, and a reverse transcription reaction was started by the addition of Superscript II reverse transcriptase (Life Technologies, Eggenstein, Germany) according to the manufacturer's instructions. Sciatic nerve RNA was added individually in tubes containing a serially decreasing amount of LIF RNA standard. This RNA standard, which functions as a competitor in the subsequent PCR, was identical to the LIF sequence except for an internal deletion of 81 bases (Sendtner et al., 1996). An aliquot of the resulting cDNA was amplified in a standard PCR with the forward primer 5'-ACCCTGTAAATGCCACCTG (located in exon 2) and the reverse primer 5'-CAACGACCATTGCTGAGGAGG (located in exon 3 of the LIF gene). The amplification product obtained thus from sciatic nerve RNA was 378 bp long; the competitor RNA gave rise to a $297 \mathrm{bp}$ reaction product. Because the concentration of the tissue RNA was kept constant in each reaction and the concentration of the competitor was varied, the resulting PCR products were at equimolar concentrations when both RNA hybridization signals were of equivalent density in autoradiograms hybridized with a specific LIF cDNA probe.

Quantification of CNTF in nerve extracts by Western blot, ELISA, and bioassay. Sciatic and facial nerves were obtained from 28 -d-old mice, shock-frozen in liquid nitrogen, and stored at $-70^{\circ} \mathrm{C}$ until use. The individual nerves were thawed in a hypotonic buffer $(5 \mathrm{~mm} \mathrm{NaPi}$ and 30 $\mathrm{mm} \mathrm{NaCl}, \mathrm{pH} 7.0$ ) and homogenized in a glass/glass homogenizer. After centrifugation for $15 \mathrm{~min}$ at $13,500 \times \mathrm{g}$, the supernatants were removed, and the protein content was determined by Bradford's Coomassie blue protein assay (Bio-Rad, Munich, Germany). Sciatic or facial nerve protein $(15 \mu \mathrm{g})$ derived from individual animals was applied per lane on a $15 \%$ polyacrylamide gel under reducing conditions. Molecular mass markers $(5 \mu \mathrm{g}$ each of lysozyme, $14.3 \mathrm{kDa}$; trypsinogen, $24 \mathrm{kDa}$; and ovalbumin, $45 \mathrm{kDa}$; Sigma, Deisenhofen, Germany) and recombinant rat CNTF (Masiakowski et al., 1991) at different concentrations were coelectrophoresed in separate lanes. After they were blotted to nitrocellulose membranes (Schleicher \& Schüll, Dassel, Germany) for $75 \mathrm{~min}$ at $150 \mathrm{~mA}$ with a semi-dry blotting apparatus (Fröbel Labortechnik, Lindau, Germany), the blots were blocked with Tris-buffered saline containing 5\% horse serum and were incubated with the monoclonal CNTF antibody 4-68 hybridoma supernatant at a dilution of 1:50. The blots were washed three times, incubated with secondary antibody (affinity-purified goat anti-mouse $\operatorname{IgG})$, and $(\mathrm{H}+\mathrm{L})$ horseradish peroxidase conjugate (Bio-Rad). After three washes the immunoreactive bands were visualized with 4-chloro-1-naphthol.

Sciatic nerves from 4-week-old control $(n=12)$ and pmn $(n=9)$ mice were prepared, and protein extracts were prepared as described above. In all, $5 \mu \mathrm{g}$ of each protein extract was subjected to ELISA analysis by applying a commercial assay kit (R \& D Systems, Wiesbaden, Germany). Recombinant rat CNTF was used as a standard, and $100 \mathrm{pg}$ was added to $5 \mu \mathrm{g}$ of each protein extract solution and analyzed in parallel as a recovery standard. Values were corrected by the calculated recovery, which was in the range of $50-80 \%$.

Ciliary ganglia were prepared from 8-d-old chick embryos. After incubation in $0.1 \%$ trypsin in $\mathrm{Ca} / \mathrm{Mg}$-free $\mathrm{PBS}$ for $30 \mathrm{~min}$ at $37^{\circ} \mathrm{C}$, the ganglia were washed three times with $5 \mathrm{ml}$ of ice-cold F14 containing $10 \%$ horse serum (Sendtner et al., 1992c). Single-cell suspensions were obtained by trituration via a siliconized Pasteur pipette, and the cells were preplated for $2.5 \mathrm{hr}$ for the enrichment of neuronal cells on a cell culture-treated plastic dish $(10 \mathrm{~cm}$; Nunc, Wiesbaden, Germany). The nonattached ciliary neurons were collected and plated at a density of 1000 cells per $16 \mathrm{~mm}$ culture dish in polyornithine/laminin-coated 24multiwell dishes (Costar, Bodenheim, Germany). F14 medium containing $10 \%$ horse serum was used as a culture medium. The protein extracts from $p m n$ and control nerves were added at different concentrations from 10 to $2500 \mathrm{ng}$. Surviving neurons were counted $24 \mathrm{hr}$ after plating, and maximal survival (in the order of $90 \%$ of plated cells) was observed with $10 \mathrm{ng} / \mathrm{ml}$ of recombinant rat CNTF. To determine the specificity of this assay, we added $4 \mu \mathrm{g}$ of purified IgG from a neutralizing rabbit CNTF antiserum (K10) per milliliter of culture medium to the highest concentration of each nerve extract sample. The addition of these antibodies abolished the survival response of the nerve extracts by $>90 \%$ but did not reduce survival effects of bFGF or IGF-I (data not shown). These data indicate that the nerves obtained from these mice did not contain an additional ciliary neuronal survival-promoting activity at concentrations up to $2500 \mathrm{ng} / \mathrm{ml}$ culture medium, as has been observed previously with nerve extracts from CNTF $+/+$ mice (Masu et al., 1993). The protein 
concentration (ng/ml) supporting half-maximal survival was defined as 1 trophic unit (TU) and corresponded to $\sim 10 \mathrm{pg}$ of pure recombinant rat CNTF.

In each group nerves from 3-12 animals were examined, and all determinations were done in duplicate. The values shown in Figure 1 represent the mean \pm SEM. Student's $t$ test was applied for statistical analysis of the results.

\section{RESULTS}

\section{CNTF protein levels and bioactivity in the sciatic and facial nerve of pmn mice}

To investigate whether endogenous expression of CNTF is altered in pmn mice, we determined levels of CNTF protein in sciatic and facial nerves of 4-week-old pmn and control mice obtained from the same litters by Western blot analysis. Figure $1 a$ shows that the intensity of CNTF immunoreactive bands was similar in mutant and wild-type mice of the same genetic background. There was a slight reduction of the signal intensity in the distal (Fig. 1, lane 4), as compared with the proximal (Fig. 1, lane 5 ), sciatic nerve in pmn mice. This probably reflects the downregulation of CNTF production occurring after the "dying back" of motor axons, which is a specific feature of the disease process in this mouse mutant. The intensity of CNTF reactive bands in facial nerves of pmn mice was slightly lower in comparison to control mice from the same litters, reflecting the loss of axons and subsequent demyelination and downregulation of endogenous CNTF synthesis. CNTF protein levels also were determined by ELISA (Fig. 1c). In sciatic nerves of 4-week-old control mice $(n=$ 12), $95.7 \pm 21.11 \mathrm{ng} / \mathrm{mg}$ protein (mean $\pm \mathrm{SEM}$ ) was measured in pmn mice $(n=9) 87.1 \pm 16.4 \mathrm{ng} / \mathrm{mg}$. The difference between the two groups was not statistically significant ( $p=0.76$ by two-tailed $t$ test).

Similar results were obtained when CNTF biological activity in nerve extracts was tested by bioassay with embryonic chick ciliary neurons. Half-maximal survival of ciliary neurons in culture was achieved at 50-200 $\mathrm{ng} / \mathrm{ml}$ of either pmn or control sciatic nerve extracts. Slightly lower levels of CNTF bioactivity were detected in nerve extracts from $p m n$ mice. However, this difference was not statistically significant ( $p$ values of 0.18 and 0.25 for sciatic and facial nerve extracts; $n$ was at least 6 for control nerves and at least 20 for pmn facial and sciatic nerves), indicating that CNTF biological activity and expression levels were comparable in control and pmn mice.

\section{LIF mRNA is not upregulated in lesioned sciatic nerves of pmn mice}

After sciatic nerve lesion in adult rats, LIF mRNA is upregulated rapidly in the proximal and distal nerve stump (Curtis et al., 1994). In unlesioned sciatic nerves of adult rats (Curtis et al., 1994) and mice (Sendtner et al., 1996), levels of LIF mRNA are very low. In our study a more than fivefold increase of LIF mRNA expression was observed in both the proximal and the distal part of the sciatic nerve at $24 \mathrm{hr}$ after transection in 3-week-old control mice (Fig. 2a). Interestingly, LIF mRNA was not upregulated in lesioned sciatic nerves of pmn mice from the same litters (Fig. 2b). The absolute levels of LIF mRNA in lesioned sciatic nerves in pmn mice were so low $(<3000$ molecules of LIF mRNA per 100 ng of total mRNA extracted from the proximal and distal parts of the lesioned nerves) that LIF is unlikely to contribute to the survival of lesioned motoneurons in these mutant mice. a

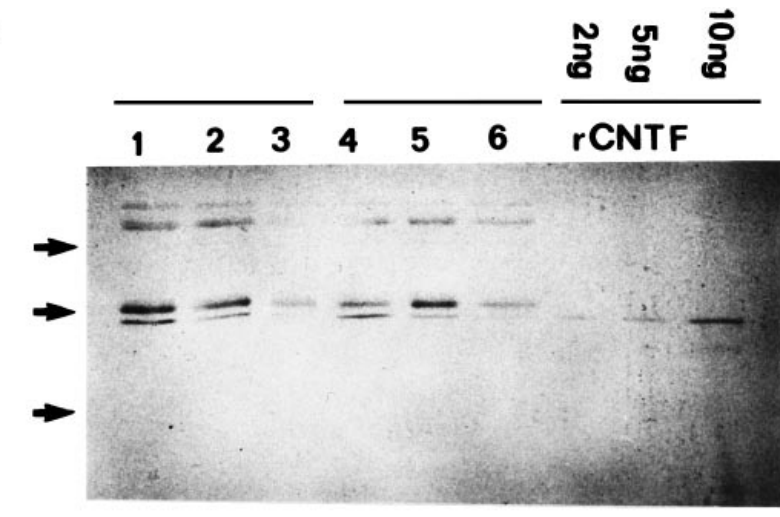

b
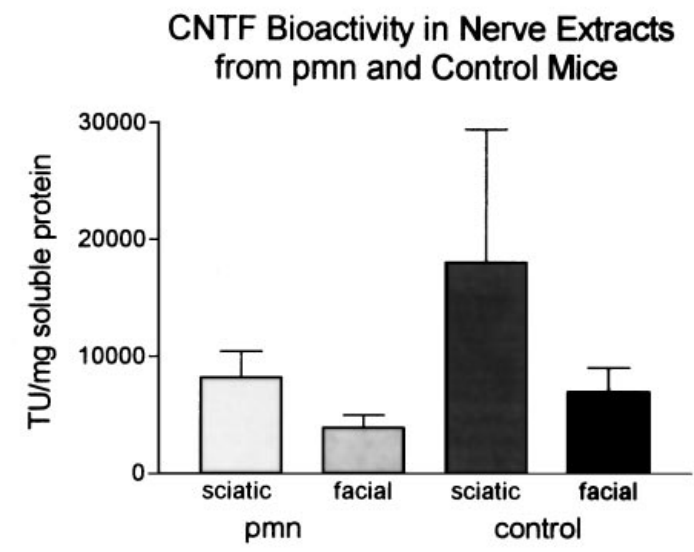

C

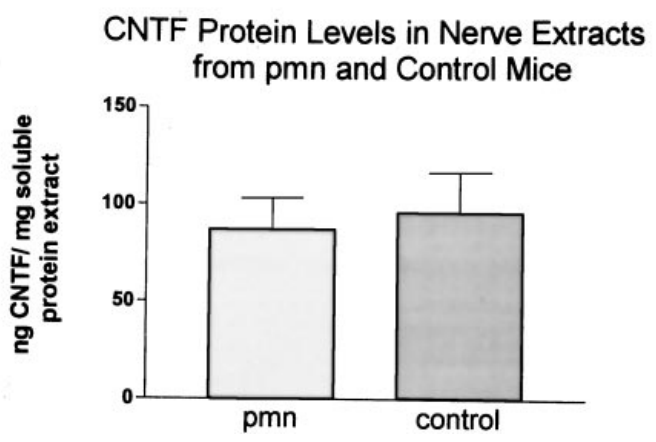

Figure 1. Levels of CNTF in sciatic and facial nerves of 4-week-old control and pmn mutant mice. $a$, The Western blot analysis of nerve extracts obtained from sciatic (lanes 1, 2, 4, and 5) and facial (lanes 3 and 6 ) nerves from 4-week-old control (lanes 1-3) and pmn (lanes 4-6) mice. Total soluble extract protein $(15 \mu \mathrm{g})$ was loaded in each lane, and recombinant CNTF $(r C N T F)$ was coelectrophoresed in separate lanes at the concentrations indicated. CNTF immunoreactive bands were detected by the 4-68 mouse monoclonal anti-CNTF antibody. The immunoreactive bands at $\sim 48 \mathrm{kDa}$ reflect endogenous immunoglobulin heavy chain. A second CNTF immunoreactive band with slightly lower molecular mass $(\sim 20 \mathrm{kDa})$ was detected in the extracts from both control and pmn mice and probably represents a proteolytic fragment of CNTF, as observed in the sciatic nerves of adult rats after nerve lesion (Sendtner et al., 1992c). Arrows at the left reflect the relative position of coelectrophoresed molecular mass standards: ovalbumin, $45 \mathrm{kDa}$; trypsinogen, 24 $\mathrm{kDa}$; and lysozyme, $14.3 \mathrm{kDa} . b, \mathrm{CNTF}$ bioactivity in sciatic and facial nerves from 4-week-old pmn and control littermates. CNTF bioactivity was determined by the embryonic chick ciliary neuronal survival assay, and the specificity was tested by the addition of neutralizing CNTF antibodies to the highest concentration of nerve extract applied (2500 $\mathrm{ng} / \mathrm{ml}) . c$, Results of ELISA analysis of CNTF concentrations in sciatic nerves of 4-week-old pmn and control mice. Values represent the mean \pm SEM of 12 (control mice) and 9 (pmn mice) determinations. The difference between the two groups was not statistically significant $(p=0.26)$. 

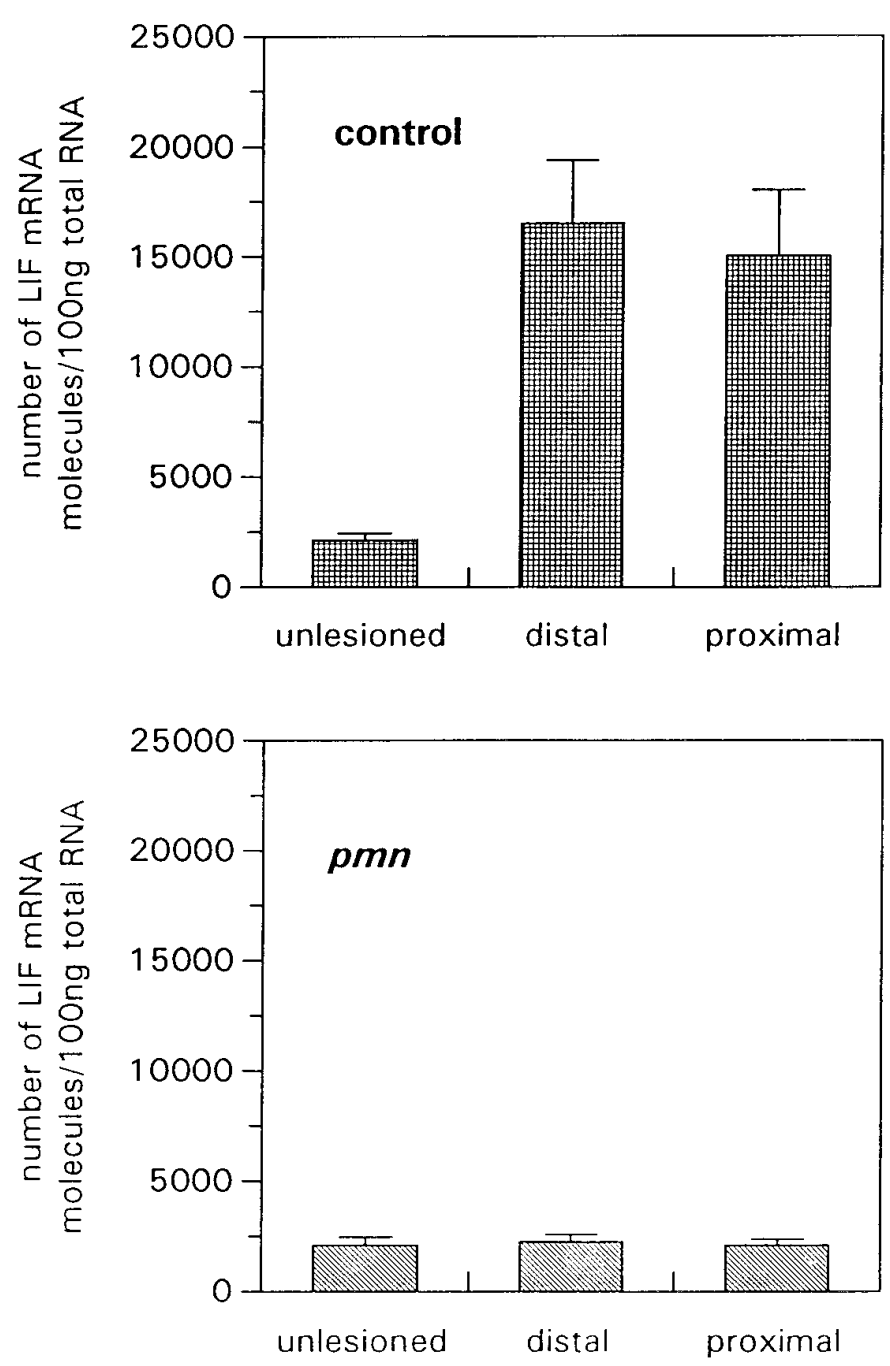

Figure 2. Quantitative analysis of LIF mRNA in sciatic nerves of pmn and control mice. The right sciatic nerve was lesioned in 3-week-old pmn mice and healthy litter mice. At $24 \mathrm{hr}$ later, the left unlesioned nerve and the proximal and distal part of the transected right nerve were prepared for RNA extraction. LIF mRNA levels are expressed as the number of LIF mRNA molecules per $100 \mathrm{ng}$ of total RNA. Values shown are the mean of at least four determinations in each group from two independent experiments. Error bars represent SD.

\section{Lesion of the facial nerve in the mouse mutant pmn leads to increased motoneuron survival}

To investigate whether peripheral nerve lesion affects motoneuron survival in 4-week-old pmn or control mice, we transected the facial nerve, and we prepared the brainstem region containing the facial nuclei from the unlesioned and the lesioned side 2 weeks later. In paraffin serial sections of this region, morphological appearance and the number of motoneurons were determined on both the lesioned and unlesioned sides. In comparison to control mice, the number of motoneurons was reduced by $40 \%(p<$ 0.005 ) on the unlesioned side (Table 1). These values are consistent with earlier studies (Sendtner et al., 1992b; Sagot et al., 1995), reflecting the degeneration of motoneurons during the disease process caused by the pmn mutation. Furthermore, most of the remaining motoneurons showed severe atrophic changes, such as reduction in Nissl structure, shrinkage, and displacement of nuclei (Fig. 3c).

In contrast to the unlesioned side, motoneuron numbers on the

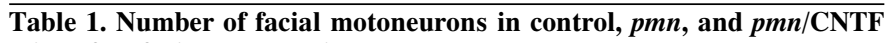
mice after facial nerve lesion

\begin{tabular}{|c|c|c|c|c|}
\hline & \multicolumn{4}{|c|}{$n$ Number of motoneurons } \\
\hline & & Control side & Lesion side & \\
\hline WT mice & 3 & $2236 \pm 131$ & $2467 \pm 66$ & N.S. \\
\hline$p m n / \mathrm{CNTF}+/+$ mice & 6 & $1299 \pm 137$ & $2043 \pm 143$ & $p<0.005$ \\
\hline $\mathrm{pmn} / \mathrm{CNTF}+/-$ mice & 4 & $1354 \pm 71$ & $1865 \pm 85$ & $p<0.005$ \\
\hline$p m n / \mathrm{CNTF}-/-$ mice & 8 & $1312 \pm 97$ & $1500 \pm 137$ & N.S. \\
\hline
\end{tabular}

Values shown represent mean \pm SEM. Statistical analysis was performed by Student's $t$ test (unpaired). The difference in the number of motoneurons on the lesioned and nonlesioned side in $p m n / \mathrm{CNTF}+/+$ and $p m n / \mathrm{CNTF}+/-$ animals was statistically significant $(p<0.005)$ but not in wild-type or $p m n / \mathrm{CNTF}-/-(p>0.05)$.

lesioned side (Fig. 3d) were significantly higher (Table 1). In comparison to control mice, the reduction in motoneuron number was much lower and did not reach statistical significance $(p>0.05)$. This indicates that the mechanisms initiated by the nerve lesion prevented the degeneration of the axotomized motoneurons.

\section{The effect of nerve lesion on motoneuron survival in pmn mice is dependent on endogenous CNTF}

To evaluate whether CNTF becoming available to the axotomized motoneurons from lesioned Schwann cells is responsible for the rescue of motoneurons after nerve lesion, we produced mice lacking endogenous $\mathrm{CNTF}$ by crossbreeding the pmn mice with $\mathrm{CNTF}-/-$ mice. In the F2 and F3 generation, animals homozygous both for the CNTF mutation and the pmn gene defect were obtained. These mice were compared with CNTF $+/+p m n / p m n$ and $\mathrm{CNTF}+/-p m n / p m n$ mice after nerve lesion at postnatal day 28. In contrast to pmn mice with endogenous CNTF expression, lesion of the facial nerve did not lead to a significant rescue of motoneurons (Fig. 3e,f). In comparison to the lesioned side, only $14 \%$ more motoneurons were detectable in comparison to $37 \%$ in $\mathrm{CNTF}+/-$ pmn/pmn mice and $57 \%$ in $\mathrm{CNTF}+/+$ pmn/pmn mice (Table 1). This indicates that the lack of endogenous CNTF leads to a significantly reduced motoneuron survival after peripheral nerve lesion.

\section{Loss of motoneurons in pmn mutant mice occurs by apoptosis}

Serial sections of brainstems from 5-week-old CNTF $+/+$ pmn/ pmn mice and CNTF -/- pmn/pmn mice were prepared and analyzed by TUNEL staining.

In $\sim 120$ sections spanning the facial nucleus of 4-week-old $\mathrm{CNTF}+/+p m n / p m n$ mice, $15.0 \pm 3.9($ mean $\pm \mathrm{SEM}, n=4)$ TUNEL-positive cells were detected on the left unlesioned side. The low number of apoptotic cell bodies reflects the narrow time window during which TUNEL-positive cells can be detected. We assume that the loss of 900 neurons on the unlesioned side (Table 1) occurs during a period of at least 2 weeks so that, on average, $\sim 65$ facial motoneurons degenerate per day in the facial nucleus of pmn mice. It is known that dying cells are eliminated rapidly in the CNS. For example, a clearance time of $1 \mathrm{hr}$ for pyknotic oligodendrocytes has been calculated (Barres et al., 1992). Thus the average number of $15.0 \pm 3.9$ apoptotic cells in the facial nucleus on the unlesioned side suggests that apoptotic motoneurons are eliminated within 5-6 hr in pmn mice. The significantly lower number of $4.3 \pm 0.9$ apoptotic cell on the lesioned side $(p<$ 0.05 by Student's $t$ test, unpaired) is another proof that nerve 



Figure 3. Morphology of facial motoneurons in normal and pmn mutant mice after nerve lesion. The facial nerve was unilaterally transected in 4-week-old mice, and histological analysis was performed from animals obtained 2 weeks later. $a, b$, Facial motoneurons from the unlesioned ( $a$ ) and (b) lesioned side of a control mouse; $c$, unlesioned side from a pmn mouse; $d$, lesioned side from a pmn mouse; $e$, unlesioned side from a pmn mouse lacking endogenous CNTF; $f$, lesioned side from a pmn mouse lacking endogenous CNTF. Scale bar, $100 \mu \mathrm{m}$.

lesion reduces the extent of apoptosis in the facial nucleus of $p m n$ mice. In CNTF $-/-$ pmn mice $(n=2)$, on average, 14 apoptotic neurons were seen both on the unlesioned (Fig. 4e,f) and lesioned sides. These data support the observation that facial nerve lesion significantly can reduce the death of lesioned motoneurons in $\mathrm{CNTF}+/+$ pmn mice, but not in CNTF $-/-$ pmn mice.

\section{DISCUSSION}

We have shown previously that the injection of CNTF-producing cells into the peritoneal cavity of 3-week-old homozygous pmn mutant mice markedly prolongs survival and improves motor performance (Sendtner et al., 1992b). This is paralleled by a corresponding reduction in motoneuron loss in the facial nucleus 
a

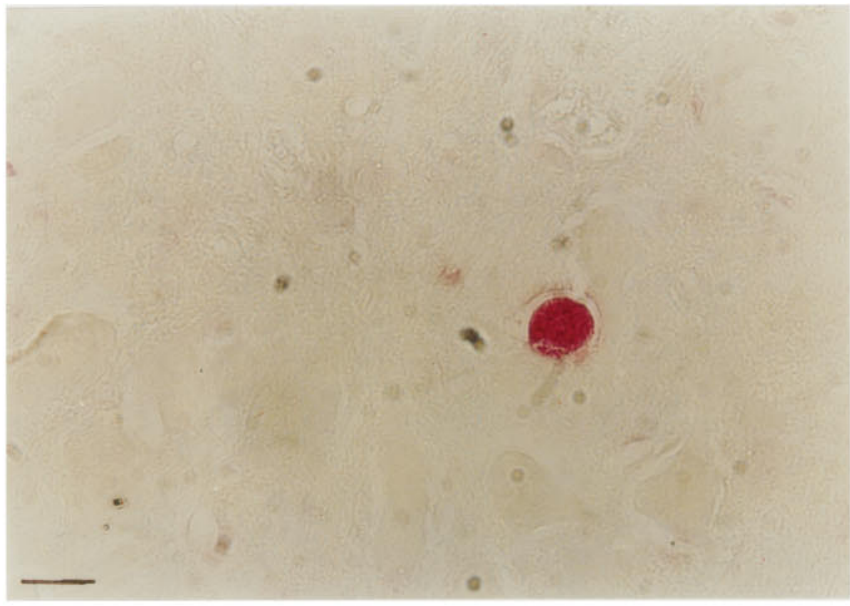

C

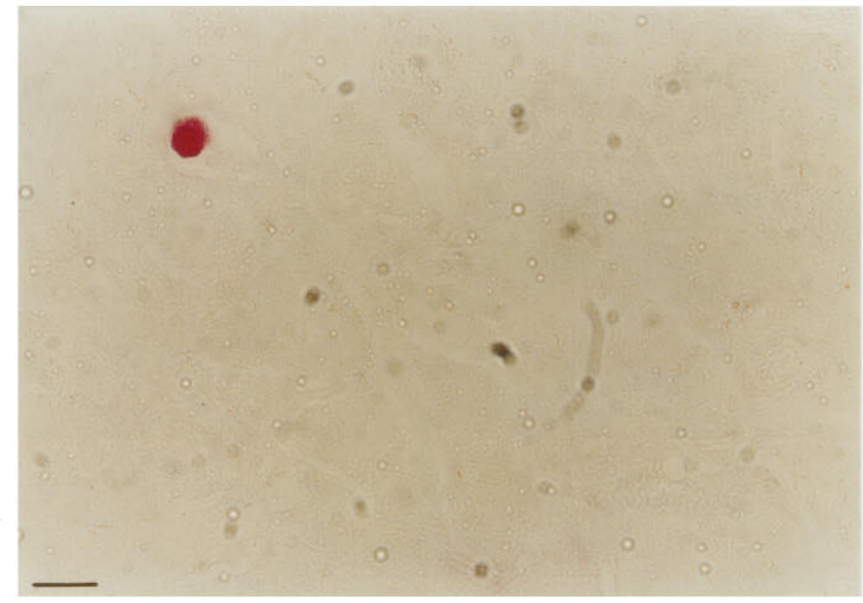

e

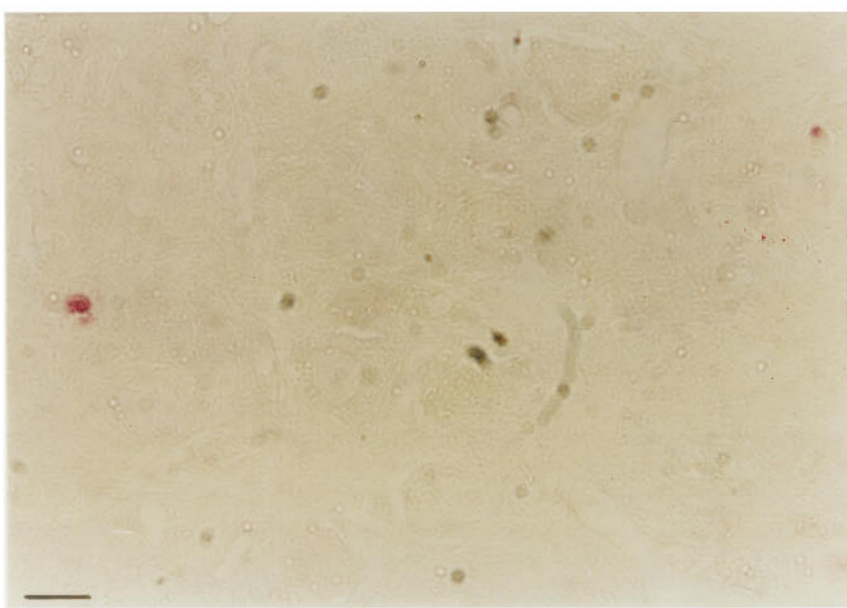

b

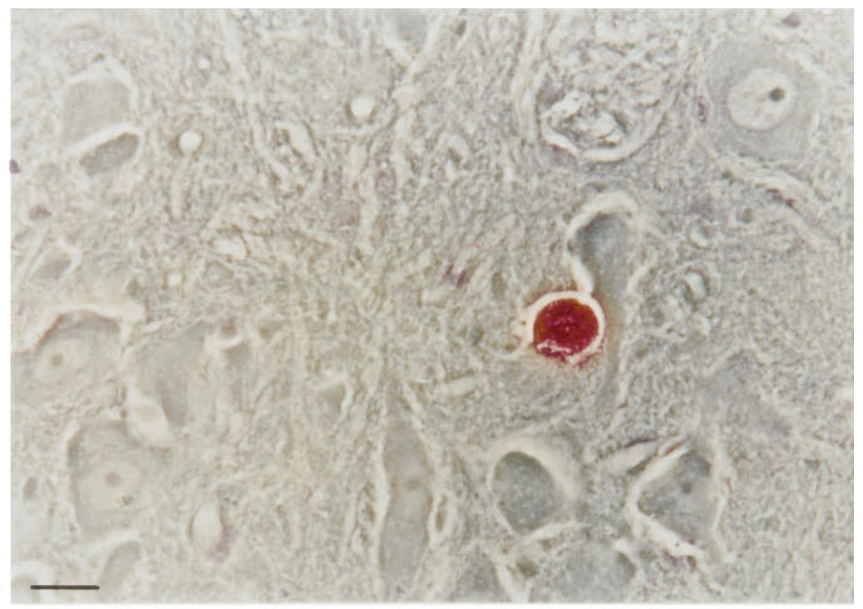

d

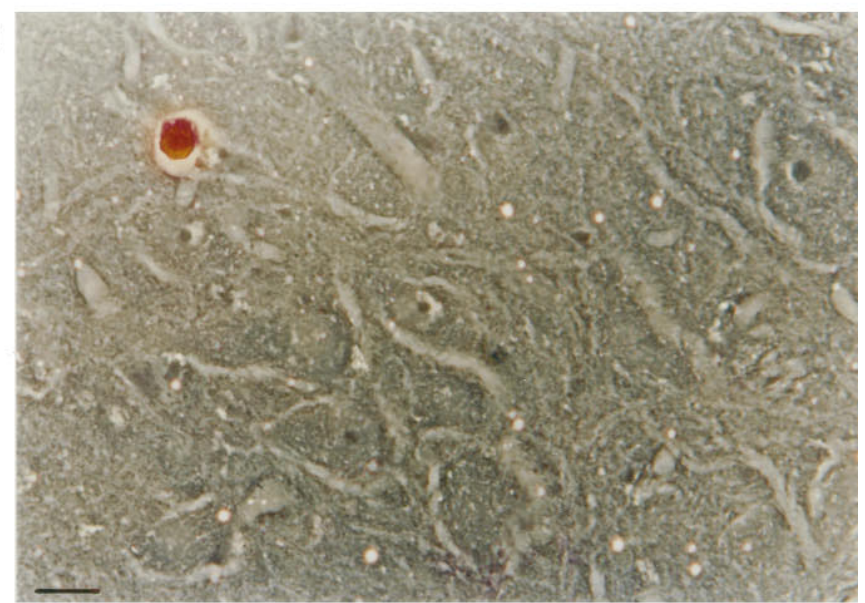

f

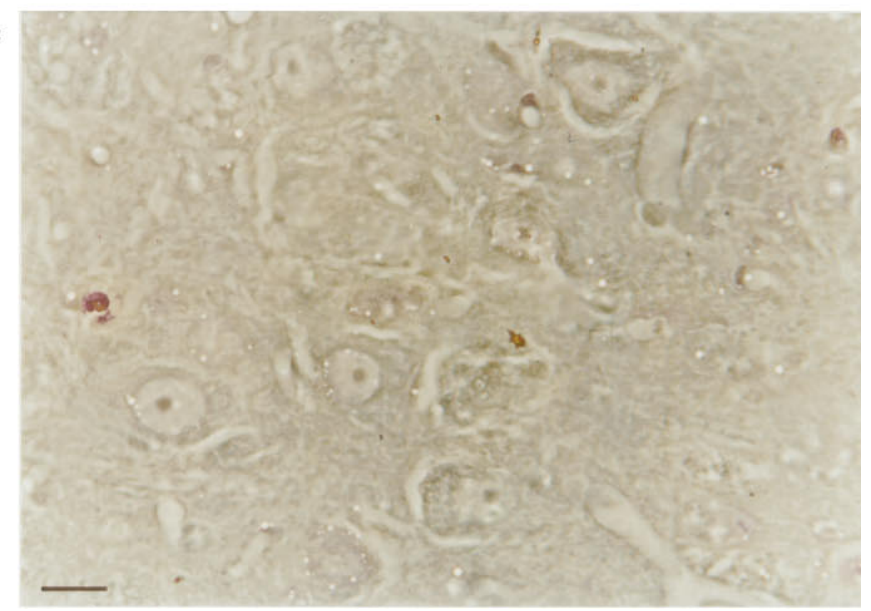

Figure 4. TUNEL staining of facial motoneurons in pmn and pmn CNTF $-/-$ mice. Paraffin serial sections $(7 \mu \mathrm{m})$ through the brainstem region containing the facial nuclei were prepared and Nissl-stained. The facial nuclei were identified, and sections covering the region of the facial nuclei on both sides were processed for TUNEL staining. TUNEL-positive cells are shown by the red alkaline phosphatase reaction product. $a, c, e$, Bright-field pictures. $b, d, f$, Phase-contrast pictures from the same sections. $a-d$, Two examples of TUNEL-positive cells in the facial nucleus of a $p m n / C N T F+/+$ mouse; $e, f$, A TUNEL-positive cell in the facial nucleus of a $p m n / \mathrm{CNTF}-/-$ mouse. Scale bar, $20 \mu \mathrm{m}$.

and in myelinating nerve fibers in the phrenic nerve. Subsequent studies by Sagot et al. (1995) that used encapsulated cell implants producing CNTF after subcutaneous implantation confirmed and extended these results insofar as it could be shown that these mice survived for periods up to several months in comparison to untreated mice that die of respiratory failure between 5 and 7 weeks after birth.

However, it is not a lack of endogenous CNTF that leads to neurodegeneration in pmn mice. CNTF protein levels in pmn mice and control mice are similar. Levels equivalent to $100 \mathrm{ng}$ 
$\mathrm{CNTF} / \mathrm{mg}$ of extractable protein are present in the sciatic nerves of both control and pmn mice. This corresponds to the levels previously determined in lesioned and unlesioned peripheral nerves of adult rats (Sendtner et al., 1992c). In terms of biological activity, $3991 \pm 1038$ (mean \pm SEM, $n=20$ ) TUs of CNTF activity were detected in the facial nerve and $8191 \pm 2250$ (mean \pm SEM, $n=20$ ) in the sciatic nerve of pmn mice. One trophic unit of CNTF supports half-maximal survival of responsive neurons in $1 \mathrm{ml}$ of cell culture medium. Therefore, the levels of CNTF protein in the lesioned nerves are very high, and only small quantities need to be released by the nerve transection to provide sufficient local concentrations of the factor to support injured motoneurons. However, it cannot be excluded that the release of CNTF also leads to local cellular reactions in the peripheral nerve, in particular in Schwann cells and probably also in invading inflammatory cells expressing gp 130 and LIFR $\beta$. Soluble CNTFR $\alpha$ from the circulation or from Schwann cells then would help to form functional CNTF receptors on these cells and lead to complex cellular responses that either directly or indirectly result in the local production of neurotrophic factors that contribute in supporting motoneuron survival.

Nevertheless, the high quantities of CNTF in peripheral nerves of adult rodents, which are at least 1000 times higher than the levels of NGF (Heumann et al., 1987a,b), suggest that a direct effect of CNTF on lesioned motoneurons is very likely. For its rescue effect in pmn motoneurons, very little CNTF is necessary. For comparison, the levels of CNTF bioactivity in the circulation of CNTF tumor cell-treated pmn mice were in the range of 500 TUs/ml serum, corresponding to $\sim 5-10 \mathrm{ng}$ of $\mathrm{CNTF} / \mathrm{ml}$ of blood (Sendtner et al., 1992b). This indicates that the endogenous CNTF in untreated pmn mice is highly abundant in comparison to the low levels of pharmacologically applied CNTF, which effectively prolonged survival and improved motor function. The only explanation for this apparent discrepancy is that the endogenous CNTF cannot rescue motoneurons, because it is not available to these cells under normal conditions.

After sciatic nerve lesion in adult rats, CNTF mRNA expression is downregulated rapidly in Schwann cells distal to the lesion site (Friedman et al., 1992; Sendtner et al., 1992c; Seniuk et al., 1992). The CNTF protein levels and bioactivity decreased much more slowly, and substantial quantities of CNTF protein and bioactivity were maintained at the lesion site and in the distal nerve stump. Moreover, CNTF immunoreactivity was detectable at sites associated with myelin breakdown products and basal membranes (Sendtner et al., 1992c). We have concluded from these findings that at least part of the CNTF at these sites seems to be extracellular and thus is available to lesioned neurons.

Mice were produced by homologous recombination in embryonic stem cells that lack endogenous CNTF (Masu et al., 1993). These mice develop normally during the first weeks after birth, but then $\sim 20 \%$ of the facial motoneurons degenerate between 8 weeks and 6 months of age. Peripheral nerve lesion in such mice does not lead to major loss of motoneurons (Sendtner et al., 1996), most probably because LIF mRNA is upregulated in the lesioned nerve (Curtis et al., 1994) and can act on motoneurons via LIFR $\beta$ and gp 130, the two signal-transducing receptor subunits that are identical in CNTF, LIF, and cardiotrophin (CT-1) receptors (for review, see Stahl and Yancopoulos, 1994). However, the levels of LIF mRNA are extremely low in unlesioned peripheral nerves (Curtis et al., 1994; Sendtner et al., 1996). Moreover, the rapid upregulation of LIF mRNA usually found after nerve lesion in adult rats and mice does not occur in pmn mice. This could explain why LIF does not rescue motoneurons in pmn mice via CNTF receptors. Nerve lesion in 4-week-old CNTF/LIF double knock-out mice leads to a significant loss of $>30 \%$ of the lesioned motoneurons (Sendtner et al., 1996). This indicates that adult motoneurons still depend on these Schwann cell-derived neurotrophic factors for their survival after axotomy. Moreover, nerve root avulsion in adult mice that removes the peripheral nerves, including the Schwann cells, results in significant motoneuron death in adult mice (Li et al., 1995), whereas the more peripheral nerve transection does not. Together, these data indicate that Schwann cells provide survival factors to lesioned motoneurons and that CNTF plays an important role in these processes.

Nothing is known so far about the expression of cardiotrophin-1, another member of the CNTF/LIF family of neurotrophic cytokines (Pennica et al., 1995a,b, 1996) in adult peripheral nerves after lesion. This factor, although lacking a conventional hydrophobic signal peptide, has been reported to be released from muscle cells and thus to be a strong candidate as a target-derived neurotrophic factor for developing motoneurons (Pennica et al., 1996). It will be interesting to determine whether CT-1 expression is reduced in pmn mice, because the disease starts at the motor end plate (Schmalbruch et al., 1991), and the lack of target-derived neurotrophic factors supporting the maintenance of these specific synapses could play an essential role in the pathogenesis of the disease.

We have performed nerve lesions in 4-week-old pmn mice and find that the lesion protects motoneurons from degeneration to a similar extent as exogenous CNTF treatment (Sendtner et al., 1992b; Sagot et al., 1995). Furthermore, the number of TUNELpositive cell bodies is reduced significantly on the lesioned side in comparison to the control side in these mutant mice. In contrast, most of the axotomized motoneurons in pmn mice lacking endogenous CNTF degenerate at a similar ratio to that in unlesioned motoneurons. We conclude from this finding that significant quantities of CNTF are released from injured Schwann cells after nerve lesion and that the factor is then available to the axons of the lesioned neurons. Furthermore, CNTF promotes survival of the lesioned adult motoneurons. This demonstrates that the CNTF located in the cytosol of myelinating Schwann cells can act as a lesion factor once it is released by nerve damage.

\section{REFERENCES}

Adler R, Landa KB, Manthorpe M, Varon S (1979) Cholinergic neurotrophic factors: intraocular distribution of trophic activity for ciliary neurons. Science 204:1434-1436.

Barbin G, Manthorpe M, Varon S (1984) Purification of the chick eye ciliary neuronotrophic factor. J Neurochem 43:1468-1478.

Barres BA, Hart IK, Coles HSR, Burne JF, Voyvodic JT, Richardson WD, Raff MC (1992) Cell death and control of cell survival in the oligodendrocyte lineage. Cell 70:31-46.

Cheema SS, Richards LJ, Murphy M, Bartlett PF (1994) Leukemia inhibitory factor rescues motoneurones from axotomy-induced cell death. NeuroReport 5:989-992.

Curtis R, Scherer SS, Somogyi R, Adryan KM, Ip NY, Zhu Y, Lindsay RM, Distefano PS (1994) Retrograde axonal transport of LIF is increased by peripheral nerve injury: correlation with increased LIF expression in distal nerve. Neuron 12:191-204.

Friedman B, Scherer SS, Rudge JS, Helgren M, Morrisey D, McClain J, Wang DY, Wiegand SJ, Furth ME, Lindsay RM, Ip NY (1992) Regulation of ciliary neurotrophic factor expression in myelin-related Schwann cells in vivo. Neuron 9:295-305.

Henderson CE, Phillips HS, Pollock RA, Davies AM, Lemeulle C, Armanini M, Simpson LC, Moffet B, Vandlen RA, Koliatsos VE (1994) GDNF: a potent survival factor for motoneurons present in peripheral nerve and muscle. Science 266:1062-1064. 
Heumann R, Korsching S, Bandtlow C, Thoenen H (1987a) Changes of nerve growth factor synthesis in non-neuronal cells in responses to sciatic nerve transection. J Cell Biol 104:1623-1631.

Heumann R, Lindholm D, Bandtlow C, Meyer M, Radeke MJ, Misko TP, Shooter EM, Thoenen H (1987b) Differential regulation of mRNA encoding nerve growth factor and its receptor in rat sciatic nerve during development, degeneration, and regeneration: role of macrophages. Proc Natl Acad Sci USA 84:8735-8739.

Hughes RA, Sendtner M, Thoenen H (1993) Members of several gene families influence survival of rat motoneurons in vitro and in vivo. J Neurosci Res 36:663-671.

Ishii DN, Glazner GW, Whalen LR (1993) Regulation of peripheral nerve regeneration by insulin-like growth factors. Ann NY Acad Sci 692:172-182.

Koliatsos VE, Clatterbuck RE, Winslow JW, Cayouette MH, Price DL (1993) Evidence that brain-derived neurotrophic factor is a trophic factor for motor neurons in vivo. Neuron 10:359-367.

Li L, Wu W, Lin LF, Lei M, Oppenheim RW, Houenou LJ (1995) Rescue of adult mouse motoneurons from injury-induced cell death by glial cell line-derived neurotrophic factor. Proc Natl Acad Sci USA 92:9771-9775.

Lin L-FH, Mismer D, Lile JD, Armes LG, Butler III ET, Vannice JL, Collins F (1989) Purification, cloning, and expression of ciliary neurotrophic factor (CNTF). Science 246:1023-1025.

Manthorpe M, Varon S (1985) Regulation of neuronal survival and neuritic growth in the avian ciliary ganglion by trophic factors. In: Growth and maturation factors (Guroff G, ed), pp 77-117. New York: Wiley.

Manthorpe M, Skaper SD, Williams LR, Varon S (1986) Purification of adult rat sciatic nerve ciliary neuronotrophic factor. Brain Res 367:282-286.

Masiakowski P, Liu H, Radziejewski C, Lottspeich F, Oberthuer W, Wong V, Lindsay RM, Furth ME, Panayotatos N (1991) Recombinant human and rat ciliary neurotrophic factors. J Neurochem 57:1003-1012.

Masu Y, Wolf E, Holtmann B, Sendtner M, Brem G, Thoenen H (1993) Disruption of the CNTF gene results in motor neuron degeneration. Nature 365:27-32.

Meyer M, Matsuoka I, Wetmore C, Olson L, Thoenen H (1992) Enhanced synthesis of brain-derived neurotrophic factor in the lesioned peripheral nerve: different mechanisms are responsible for the regulation of BDNF and NGF mRNA. J Cell Biol 119:45-54.

Oppenheim RW, Houenou LJ, Johnson JE, Lin LF, Li L, Lo AC, Newsome AL, Prevette DM, Wang S (1995) Developing motor neurons rescued from programmed and axotomy-induced cell death by GDNF. Nature 373:344-346.

Pennica D, King KL, Shaw KJ, Luis E, Rullamas J, Luoh SM, Darbonne WC, Knutzon DS, Yen R, Chien KR (1995a) Expression cloning of cardiotrophin 1, a cytokine that induces cardiac myocyte hypertrophy. Proc Natl Acad Sci USA 92:1142-1146.

Pennica D, Shaw KJ, Swanson TA, Moore MW, Shelton DL, Zioncheck KA, Rosenthal A, Taga T, Paoni NF, Wood WI (1995b) Cardiotrophin-1. Biological activities and binding to the leukemia inhibitory factor receptor/gp130 signaling complex. J Biol Chem 270:10915-10922.

Pennica D, Arce V, Swanson TA, Vejsada R, Pollock RA, Armanini M, Dudley K, Phillips HS, Rosenthal A, Kato AC, Henderson CE (1996)
Cardiotrophin-1, a cytokine present in embryonic muscle, supports long-term survival of spinal motoneurons. Neuron 17:63-74.

Rende M, Muir D, Rouslathi E, Hagg T, Varon S, Manthorpe M (1992) Immunolocalization of ciliary neuronotrophic factor in adult rat sciatic nerve. Glia 5:25-32.

Sagot Y, Tan SA, Baetge E, Schmalbruch H, Kato AC, Aebischer P (1995) Polymer encapsulated cell lines genetically engineered to release ciliary neurotrophic factor can slow down progressive motor neuronopathy in the mouse. Eur J Neurosci 7:1313-1322.

Schmalbruch H, Jensen HJS, Bjaerg M, Kamieniecka Z, Kurland L (1991) A new mouse mutant with progressive motor neuronopathy. J Neuropathol Exp Neurol 50:192-204.

Sendtner M, Kreutzberg GW, Thoenen H (1990) Ciliary neurotrophic factor prevents the degeneration of motor neurons after axotomy. Nature 345:440-441.

Sendtner M, Holtmann B, Kolbeck R, Thoenen H, Barde Y-A (1992a) Brain-derived neurotrophic factor prevents the death of motoneurons in newborn rats after nerve section. Nature 360:757-758.

Sendtner M, Schmalbruch H, Stöckli KA, Carroll P, Kreutzberg GW, Thoenen H (1992b) Ciliary neurotrophic factor prevents degeneration of motor neurons in mouse mutant progressive motor neuronopathy. Nature 358:502-504.

Sendtner M, Stöckli KA, Thoenen H (1992c) Synthesis and location of ciliary neurotrophic factor in the rat sciatic nerve of the adult rat after lesion and during regeneration. J Cell Biol 118:139-148.

Sendtner M, Carroll P, Holtmann B, Hughes RA, Thoenen H (1994) Ciliary neurotrophic factor. J Neurobiol 25:1436-1453.

Sendtner M, Götz R, Holtmann B, Escary J-L, Masu Y, Carroll P, Wolf E, Brehm G, Brulet P, Thoenen H (1996) Cryptic physiological trophic support of motoneurons by LIF disclosed by double gene targeting of CNTF and LIF. Curr Biol 6:686-694.

Seniuk N, Altares M, Dunn R, Richardson PM (1992) Decreased synthesis of ciliary neurotrophic factor in degenerating peripheral nerves. Brain Res 572:300-302.

Stahl N, Yancopoulos GD (1994) The tripartite CNTF receptor complex: activation and signaling involves components shared with other cytokines. J Neurobiol 25:1454-1466.

Stöckli KA, Lottspeich F, Sendtner M, Masiakowski P, Carroll P, Götz R, Lindholm D, Thoenen H (1989) Molecular cloning, expression, and regional distribution of rat ciliary neurotrophic factor. Nature 342:920-923.

Stöckli KA, Lillien LE, Näher-Noe M, Breitfeld G, Hughes RA, Thoenen H, Sendtner M (1991) Regional distribution, developmental changes, and cellular localization of CNTF mRNA and protein in the rat brain. J Cell Biol 115:447-459.

Trupp M, Ryden M, Jornvall H, Funakoshi H, Timmusk T, Arenas E, Ibanez CF (1995) Peripheral expression and biological activities of GDNF, a new neurotrophic factor for avian and mammalian peripheral neurons. J Cell Biol 130:137-148.

Yan Q, Elliott J, Snider WD (1992) Brain-derived neurotrophic factor rescues spinal motor neurons from axotomy-induced cell death. Nature 360:753-755.

Zurn AD, Baetge EE, Hammang JP, Tan SA, Aebischer P (1994) Glial cell line-derived neurotrophic factor (GDNF), a new neurotrophic factor for motoneurones. NeuroReport 6:113-118. 